\title{
Pearls \& Oy-sters: Adolescent-onset adrenomyeloneuropathy and arrested cerebral adrenoleukodystrophy
}

Jieru E. Lin, MD, PhD, Eric A. Armour, MD, PhD, Arezou Heshmati, MD, Christine Umandap, MD, Julia J. Couto, MD, Alejandro D. Iglesias, MD, Eric J. Mallack, MD, and Jennifer M. Bain, MD, PhD

Neurology ${ }^{\circledR}$ 2019;93:81-84. doi:10.1212/WNL.0000000000007755

\section{Pearls}

- Defects in peroxisomal transport interferes with $\beta$-oxidation of very long chain fatty acids (VLCFAs). Subsequent VLCFA accumulation triggers a cascade of events that eventually leads to adrenoleukodystrophy (ALD).

- Attention-deficit/hyperactivity disorder (ADHD) can be one of the early manifestations of childhood cerebral ALD (CCALD).

- Patients with adrenomyeloneuropathy (AMN) may have signs of occult self-halted CCALD on MRI, which can help point to a diagnosis of AMN.

\section{Oy-sters}

- AMN can present in adolescence, although it typically presents in adult men between 20 and 40 years of age, and at older age in women.

- MRI findings in the spinal cord could be normal or show minimal white matter involvement with significant bilateral spastic paraparesis.

- Blood pressure, glucose, and electrolytes can be normal in patients with adrenal insufficiency.

A 19-year-old man with autism spectrum disorder (ASD) and ADHD presented with a 3-week history of acute progression of bilateral leg weakness associated with stiffness and gait instability. The symptoms started insidiously 2 years prior ( 17 years of age), with $1-2$ falls per week, and were associated with numbness and tingling below the knees bilaterally. Initially, the patient was able to stand up from a chair without support and walk on his toes with support for 3-5 steps. Over the last year, the patient began to experience bilateral flexor spasms in his legs at rest. He had urinary incontinence once weekly, which worsened to nightly over the 3 nights prior to evaluation. Otherwise, review of systems was unremarkable without recent infectious symptoms, lower back pain, or skin changes. No recent trauma or changes in lifestyle, diet, or exercise were reported. There was no relevant travel or family history or history of consanguinity.

The patient's vital signs were within normal range. The examination was significant for $4 / 5$ strength in bilateral hip and knee flexion and $3 / 5$ in bilateral ankle dorsiflexion. Spasticity was noted in the lower extremities bilaterally. His sensory examination was intact to fine touch and pinprick in all 4 extremities but decreased to vibration starting at the knee and extending distally below L3 in a nondermatomal pattern. Joint position sense was absent at the toes, but intact proximally. Romberg sign was positive. Cerebellar examination was unremarkable. Reflexes were 3+ throughout with crossed adductors with bilateral ankle clonus and the presence of Babinski signs. He had a spastic gait, dragging both feet and unable to perform tandem gait.
Correspondence

Dr. Bain

jb3634@cumc.columbia.edu 
Overall, the examination was abnormal with spastic paraparesis and a posterolateral cord syndrome without cognitive involvement.

Infectious and autoimmune evaluations were unremarkable, including human T-cell lymphotropic virus 1, cytomegalovirus, HIV, Lyme serologies, rapid plasma reagin, C-reactive protein, erythrocyte sedimentation rate, serum protein electrophoresis, urine protein electrophoresis, rheumatoid factor, extractable nuclear antigen, anti-gliadin antibodies, anti-tissue transglutaminase antibodies, anti-endomysial antibodies, antisulfide antibodies, hepatitis, paraneoplastic, ganglioside, and antinuclear antibodies panel. Vitamin levels, including $B_{6}, B_{12}$, methylmalonic acid, homocysteine, vitamin E, copper, ceruloplasmin, and zinc, were within normal limits.

Brain MRI with contrast showed a non-contrast-enhancing, high T2/fluid-attenuated inversion recovery signal abnormality in the periventricular white matter adjacent to the posterior body of both lateral ventricles extending into and crossing the splenium of the corpus callosum (figure, C). These findings were similar to the findings on MRI obtained 1 week prior at a different hospital, which at the time was reported as nonspecific (figure, B) based on similar findings on MRI performed 11 years earlier for an unrelated chief complaint of head trauma. The 2007 scan was originally read as normal due to lack of clinical correlations; however, on review, evidence of the same $\mathrm{T} 2$ abnormality was present (figure, A). Cervical, thoracic, and lumbar spinal MRI with contrast showed possible subtle intramedullary signal abnormality in the lower thoracic spinal cord at roughly the T6-T9 level, which was most likely due to artifact from breathing (appendix 2, doi.org/10.5061/dryad.qk54fq6).

Given the clues from the brain MRI, and after an extensive unremarkable autoimmune, infectious, vascular, and nutritional evaluation, the remaining diseases on the differential diagnosis were hereditary spastic paraplegia and ALD presenting as AMN with evidence of self-halted (or arrested) CCALD. Targeted genetic testing and VLCFA levels were sent. VLCFA panel showed an elevation of C26, C24, and C26/C22 ratio, supportive of X-linked ALD. Genetic testing revealed a novel c.143_155del13insAG pathogenic variant in the $A B C D 1$ gene, leading to a frameshift mutation and premature stop codon at position 143, thus confirming the diagnosis.

Evaluation of the patient's adrenal axis showed normal electrolytes, glucose, and blood pressures without reported symptoms of adrenal insufficiency, including fatigue, hyperpigmentation, erectile dysfunction, nausea, or orthostatic hypotension. However, despite being asymptomatic, AM cortisol level and ACTH stimulation test results were consistent with adrenal insufficiency (ACTH 1,149 pg/mL; cortisol: baseline $2.03 \mu \mathrm{g} / \mathrm{dL}, 60$ minutes poststimulation w/0.25 mg IVP, $4.73 \mu \mathrm{g} / \mathrm{dL}$ ). Hydrocortisone $7.5 \mathrm{mg}$ every 8 hours was supplemented for adrenal insufficiency.
The patient was started on oral baclofen and $\mathrm{O}$. botulinum was administered as injections to the gastrocnemius and hamstring muscles bilaterally for spasticity. The patient was transferred to an acute inpatient rehabilitation center and is followed by a subspecialist for management of his AMN.

\section{Discussion}

ALD is the most common inherited peroxisomal disorder with an incidence of $1: 16,800$. ALD comprises different phenotypes that are caused by defects in the $A B C D 1$ gene (ATP-binding cassette, subfamily D, member 1), which encodes a half-transporter that imports CoA-activated VLCFA into the peroxisome for degradation. ${ }^{1}$ Abnormal VLCFA metabolism predominantly affects tissues in the endocrine and nervous systems. ${ }^{2}$ However, there is no specific genotype-phenotype correlation. ${ }^{1}$ The same mutation can lead any ALD phenotype: asymptomatic, Addison-only, AMN, or CCALD. ${ }^{2}$

Eighty percent of boys with CCALD undergo inflammatory demyelination that rapidly progresses to death in 2-5 years. Twenty percent of patients with CCALD will have spontaneous arrest of disease. ${ }^{2}$ Most often, CCALD lesions form in the midline of the corpus callosum and bilateral periventricular white matter. CCALD mainly affects boys younger than 12 years, and less frequently affects adolescents or adults. ${ }^{3,4}$ Demyelination begins with destabilization of myelin sheaths by accumulated VLCFAs followed by myelin breakdown. The process can halt or become inflammatory, which subsequently leads to rapid disease progression. Cerebral inflammation is mediated by oxidative stress, activation of macrophages, microglial apoptosis, and endothelial dysfunction, which ultimately damages the blood-brain barrier. ${ }^{2,4,5}$ Inflammation is diagnosed on MRI by contrast enhancement in the "leading edge" of the CCALD lesion. ${ }^{6}$

AMN is primarily viewed as the adult-onset phenotype of X-linked ALD. ${ }^{7}$ AMN typically presents in adult men between 20 and 40 years of age, with the earliest onset reported at 14 years of age. ${ }^{7}$ Sixty percent of female patients in late adulthood and nearly all male ALD patients will develop AMN eventually. ${ }^{1}$ The main symptoms include gait difficulties (100\%) and bowel or bladder problems (80\%-100\%) and adrenal insufficiency $(50 \%-80 \%))^{1,5,7}$ The current pathogenic hypotheses suggest that impaired mitochondrial function, subsequent oxidative stress, and energy depletion contribute to a dying-back axonopathy. ${ }^{1}$ This differs from the aforementioned hypotheses for CCALD. ${ }^{4}$

Our patient had evidence of a brain lesion in the periventricular white matter and splenium that developed before age 8 , as evidenced on his first MRI (figure, A). Because the findings were subtle, the MRI was read as normal. Due to the normal read and lack of symptoms, he did not have repeat imaging until the current presentation of acute gait decline. 

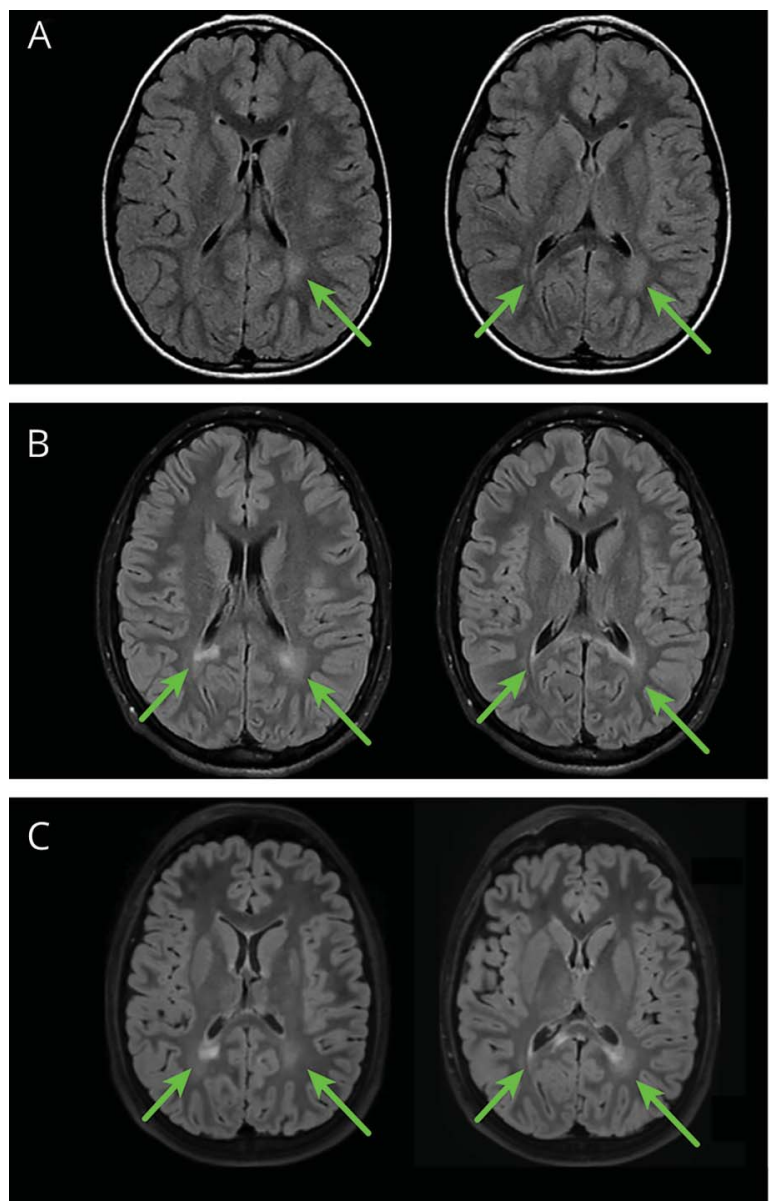
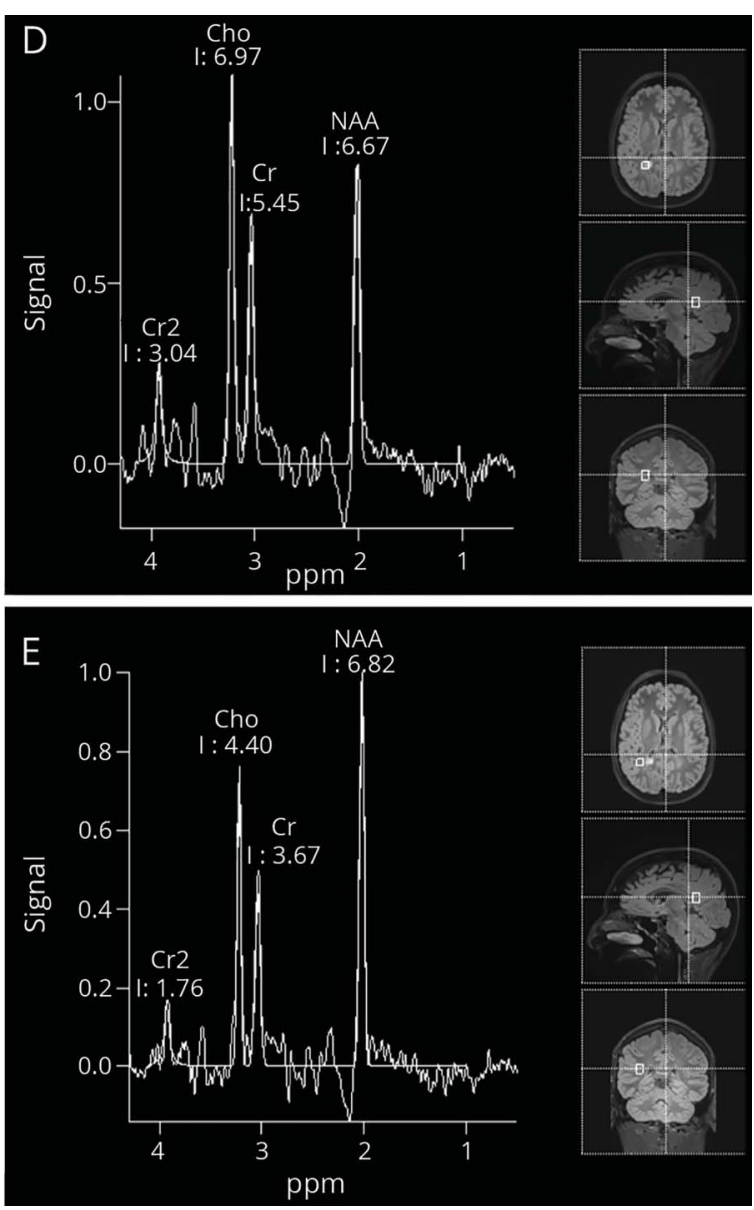

(A) MRI from October 2007 reported as normal. Note subtle posterior periatrial white matter T2 hyperintensities (green arrows). (B) MRI from August 2008 with extension of the T2 abnormality across the splenium. (C) MRI 3.5 months later (November 2018) demonstrates stable T2 hyperintensity. (D) Voxel placed within T2 lesion demonstrates inversion of the choline (Cho) and $\mathrm{N}$-acetylaspartate (NAA) peaks. (E) Voxel placed in normal-appearing white matter outside the T2 lesion demonstrates normal posterior white matter NAA/creatine $(\mathrm{Cr})$ and $\mathrm{Cho/Cr}$ ratios.

His lesion grew minimally between 2007 and 2018 and showed no perilesional changes on magnetic resonance (MR) spectroscopy or MR perfusion, thus supporting a diagnosis of self-halted CCALD (figure). ${ }^{6,8}$ Pairing the relatively specific finding of an isolated splenial lesion in a patient with worsening lower extremity weakness and spasticity raised the suspicion for AMN, of which the clinical presentation is highly variable without identifiable precipitating factors.

In addition, the patient was diagnosed with ASD and ADHD in childhood, both neurodevelopmental conditions diagnosed in children that are commonly comorbid. Interestingly, many children with ALD are initially diagnosed with new attention difficulties and behavioral difficulties, so ALD should be always be entertained as a differential diagnosis to idiopathic ADHD. These behaviors in a previously healthy child may delay diagnosis and potential life-saving treatment. A complete neurologic examination for boys with ASD or ADHD should be performed with awareness to prevent delayed diagnosis of ALD.
Dietary therapies, antioxidants, and medications that normalize or lower the levels of VLCFA in the plasma of patients have not yielded significant effects on alteration of the rate of disease progression in symptomatic children. ${ }^{3}$ Lorenzo's oil, a combination of 4:1 mix of oleic acid and erucic acid extracted from rapeseed oil and olive oil, was designed to normalize the accumulation of VLCFAs in the brain to slow the progression of ALD. This dietary therapy can be offered to asymptomatic boys with normal brain MRI between 18 months and 8 years of age; however, it has not been shown to alter the natural history of disease. Hematopoietic stem cell therapy, and now ex vivo gene therapy, successfully arrests disease progression in asymptomatic children. It is less effective in children with established neurologic dysfunction. ${ }^{3,9,10}$ Neither stem cell therapy is expected to have an effect on AMN or adrenal insufficiency. There are currently no effective treatments in stabilizing or reversing the progression of $\mathrm{AMN}^{3}$

Adrenal hormone replacement is mandatory for all patients with adrenal insufficiency. ${ }^{2}$ Patients with adrenal insufficiency may remain asymptomatic, as seen in our patient. The 
diagnosis of AMN could have been further delayed if lack of adrenal symptoms precluded clinical testing. It is not uncommon for patients to have subclinical adrenal disease and therefore not fulfill the classic triad of AMN: gait abnormalities and bowel and bladder dysfunction with symptomatic adrenal insufficiency. Clinical suspicion for AMN should be high in an adolescent with new-onset spastic paraparesis and impaired vibration and proprioception in the lower extremities, especially in the presence of a symmetrical periventricular lesion on MRI, despite the absence of adrenal insufficiency.

\section{Study funding}

No targeted funding reported. Dr. Eric J. Mallack receives research support from NINDS (5 K12 NS066274-08).

\section{Disclosure}

J. Lin, E. Armour, A. Heshmati, C. Umandap, J. Couto, and A. Iglesias report no disclosures relevant to the manuscript. E. Mallack receives research support from NINDS (5 K12 NS066274-08). J. Bain reports no disclosures relevant to the manuscript. Go to Neurology.org/ $\mathrm{N}$ for full disclosures.

Appendix Authors

\begin{tabular}{|c|c|c|c|}
\hline Name & Role & Location & Contribution \\
\hline $\begin{array}{l}\text { Jieru E. Lin, } \\
\text { PhD }\end{array}$ & Author & $\begin{array}{l}\text { University of Illinois } \\
\text { College of Medicine in } \\
\text { Chicago }\end{array}$ & $\begin{array}{l}\text { Drafted the manuscript } \\
\text { for intellectual content, } \\
\text { intellectual content for } \\
\text { patient care, } \\
\text { interpreted the data }\end{array}$ \\
\hline $\begin{array}{l}\text { Eric } \\
\text { Armour, } \\
\text { MD, PhD }\end{array}$ & Author & $\begin{array}{l}\text { Columbia University } \\
\text { College of Physicians } \\
\text { and Surgeons, New } \\
\text { York }\end{array}$ & $\begin{array}{l}\text { Revised the manuscript } \\
\text { for intellectual content, } \\
\text { intellectual content for } \\
\text { patient care, } \\
\text { interpreted the data }\end{array}$ \\
\hline $\begin{array}{l}\text { Arezou } \\
\text { Heshmati, } \\
\text { MD }\end{array}$ & Author & $\begin{array}{l}\text { Columbia University } \\
\text { College of Physicians } \\
\text { and Surgeons, New } \\
\text { York }\end{array}$ & $\begin{array}{l}\text { Intellectual content for } \\
\text { patient care, } \\
\text { interpreted the data }\end{array}$ \\
\hline $\begin{array}{l}\text { Christine } \\
\text { Umandap, } \\
\text { MD }\end{array}$ & Author & $\begin{array}{l}\text { Columbia University } \\
\text { College of Physicians } \\
\text { and Surgeons, New } \\
\text { York }\end{array}$ & $\begin{array}{l}\text { Intellectual content for } \\
\text { patient care, } \\
\text { interpreted the data }\end{array}$ \\
\hline
\end{tabular}

Appendix (continued)

\begin{tabular}{llll}
\hline Name & Role & Location & Contribution \\
\hline $\begin{array}{l}\text { Julia } \\
\text { Couto, MD }\end{array}$ & Author & $\begin{array}{l}\text { Columbia University } \\
\text { College of Physicians } \\
\text { and Surgeons, New } \\
\text { York }\end{array}$ & $\begin{array}{l}\text { Intellectual content for } \\
\text { patient care, } \\
\text { interpreted the data }\end{array}$ \\
\hline $\begin{array}{l}\text { Alejandro } \\
\text { D. Iglesias, } \\
\text { MD }\end{array}$ & Author & $\begin{array}{l}\text { Columbia University } \\
\text { College of Physicians } \\
\text { and Surgeons, New } \\
\text { York }\end{array}$ & $\begin{array}{l}\text { Reviewed the } \\
\text { manuscript for } \\
\text { intellectual content, } \\
\text { intellectual content for } \\
\text { patient care, } \\
\text { interpreted the data }\end{array}$ \\
\hline $\begin{array}{l}\text { Eric J. } \\
\text { Mallack, } \\
\text { MD }\end{array}$ & Author & $\begin{array}{l}\text { Weill Cornell } \\
\text { Medicine, New York- } \\
\text { Presbyterian } \\
\text { Hospital, New York }\end{array}$ & $\begin{array}{l}\text { Interpreted/acquisition } \\
\text { the data, revised the } \\
\text { manuscript for } \\
\text { intellectual content, } \\
\text { intellectual content for } \\
\text { patient care }\end{array}$ \\
& & &
\end{tabular}

\begin{tabular}{|c|c|c|c|}
\hline $\begin{array}{l}\text { Jennifer M. } \\
\text { Bain, MD, } \\
\text { PhD }\end{array}$ & Author & $\begin{array}{l}\text { Columbia University } \\
\text { College of Physicians } \\
\text { and Surgeons, New } \\
\text { York }\end{array}$ & $\begin{array}{l}\text { Revised the manuscript } \\
\text { for intellectual content, } \\
\text { major role in } \\
\text { intellectual content for } \\
\text { patient care, } \\
\text { interpreted the } \\
\text { patient's clinical data }\end{array}$ \\
\hline
\end{tabular}

\section{References}

1. Berger J, Forss-Petter S, Eichler FS. Pathophysiology of X-linked adrenoleukodystrophy. Biochimie 2014;98:135-142.

2. Moser HW, Mahmood A, Raymond GV. X-linked adrenoleukodystrophy. Nat Clin Pract Neurol 2007;3:140-151.

3. Eichler F, Duncan C, Musolino PL, et al. Hematopoietic stem-cell gene therapy for cerebral adrenoleukodystrophy. N Engl J Med 2017;377:1630-1638.

4. Eichler F, Mahmood A, Loes D, et al. Magnetic resonance imaging detection of lesion progression in adult patients with X-linked adrenoleukodystrophy. Arch Neurol 2007; 64:659-664.

5. Engelen M, Kemp S, Poll-The BT. X-linked adrenoleukodystrophy: pathogenesis and treatment. Curr Neurol Neurosci Rep 2014;14:486.

6. Musolino PL, Rapalino O, Caruso P, Caviness VS, Eichler FS. Hypoperfusion predicts lesion progression in cerebral X-linked adrenoleukodystrophy. Brain 2012;135: $2676-2683$.

7. Kohler W, Curiel J, Vanderver A. Adulthood leukodystrophies. Nat Rev Neurol 2018; 14:94-105.

8. Eichler FS, Barker PB, Cox C, et al. Proton MR spectroscopic imaging predicts lesion progression on MRI in X-linked adrenoleukodystrophy. Neurology 2002;58:901-907.

9. Miller WP, Rothman SM, Nascene D, et al. Outcomes after allogeneic hematopoietic cell transplantation for childhood cerebral adrenoleukodystrophy: the largest singleinstitution cohort report. Blood 2011;118:1971-1978.

10. Mahmood A, Raymond GV, Dubey P, Peters C, Moser HW. Survival analysis of haematopoietic cell transplantation for childhood cerebral X-linked adrenoleukodystrophy: a comparison study. Lancet Neurol 2007;6:687-692.

\section{Subspecialty Alerts by E-mail!}

Customize your online journal experience by signing up for e-mail alerts related to your subspecialty or area of interest. Access this free service by clicking on the "My Alerts" link on the home page. An extensive list of subspecialties, methods, and study design choices will be available for you to choose from-allowing you priority alerts to cutting-edge research in your field! 


\section{Neurology}

\section{Pearls \& Oy-sters: Adolescent-onset adrenomyeloneuropathy and arrested cerebral adrenoleukodystrophy}

Jieru E. Lin, Eric A. Armour, Arezou Heshmati, et al.

Neurology 2019;93;81-84

DOI 10.1212/WNL.0000000000007755

\section{This information is current as of July 8, 2019}

Updated Information \&
Services
References
Citations
Subspecialty Collections
Permissions \& Licensing
Reprints

Updated Information \&

\section{References}

Citations

\section{Subspecialty Collections}

Reprints including high resolution figures, can be found at: http://n.neurology.org/content/93/2/81.full

This article cites 10 articles, 2 of which you can access for free at: http://n.neurology.org/content/93/2/81.full\#ref-list-1

This article has been cited by 2 HighWire-hosted articles: http://n.neurology.org/content/93/2/81.full\#\#otherarticles

This article, along with others on similar topics, appears in the following collection(s):

Leukodystrophies

http://n.neurology.org/cgi/collection/leukodystrophies

Information about reproducing this article in parts (figures,tables) or in its entirety can be found online at:

http://www.neurology.org/about/about_the_journal\#permissions

Information about ordering reprints can be found online:

http://n.neurology.org/subscribers/advertise

Neurology ${ }^{\circledR}$ is the official journal of the American Academy of Neurology. Published continuously since 1951, it is now a weekly with 48 issues per year. Copyright () 2019 American Academy of Neurology. All rights reserved. Print ISSN: 0028-3878. Online ISSN: 1526-632X.

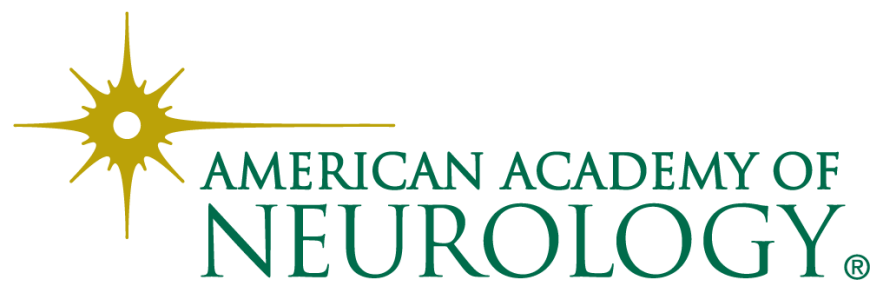

